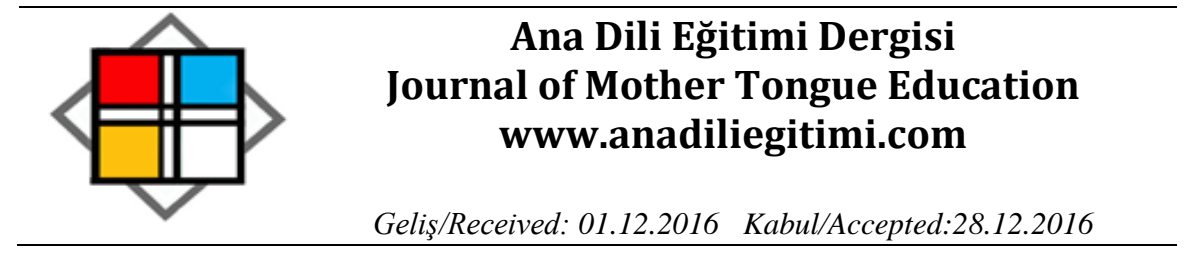

\title{
Okul Öncesi Eğitim Programı Etkinlik Kitabındaki Etkinliklerin Ses Bilgisi Farkındalığı Açısından İncelenmesi
}

\author{
Hülya KARTAL* \\ Fatih GÜNER**
}

\section{Öz}

Okul Öncesi Eğitim Programı Etkinlik Kitabı’ndaki etkinliklerin ses bilgisi farkındalığı açısından incelenmesinin amaçlandığı araştırmada, veriler doküman incelemesi yöntemiyle toplanmıştır. Okul Öncesi Eğitim Programı’nın dil gelişimi alanındaki “Sesbilgisi farkındalığı gösterir.” kazanımının yer aldığı etkinlik örneklerinin tespitine yönelik incelemelerin yapıldığı araştırmada, Okul Öncesi Eğitim Programı Etkinlik Kitabındaki etkinlik örneklerinde, "Ses bilgisi farkındalığı gösterir." kazanımının bulunduğu bir etkinlik olmadığı belirlenmiştir. Ayrıca, Okul Öncesi Eğitim Programı Etkinlik Kitabı'ndaki 40 etkinlikten "Ses bilgisi farkındalığı gösterir." kazanımını ve bu kazanımın göstergelerini destekleyebilecek 7 etkinliğin bulunduğu sonucuna ulaşılmıştır. Bu sonuçlar, okulöncesi eğitim kurumlarına devam eden çocukların sesbilgisel farkındalık gelişimlerinin desteklenebilmesi için Okul Öncesi Eğitim Programındaki etkinliklerin bu açıdan geliştirilmesine gereksinim duyulduğunu göstermektedir.

Anahtar Kelimeler: Okul öncesi eğitim programı, etkinlik, dil gelişimi, sesbilgisi farkındalığı.

\section{Analysis of the Activities in the Activity Book Preschool Education Program in Terms of Phonetic Awareness}

\begin{abstract}
In this study, which aims to examine the activities in the activity book of the Preschool Education Program in terms of phonetics awareness, the data were collected using the document analysis method. The study attempted to determine the examples of activities prepared to achieve the outcome "The student shows awareness for phonetics" in the area of language development of the Preschool Education Program and it was concluded that there was no activity that could lead to the outcome "The student shows awareness for phonetics" among the activities in the Preschool Education Program activity book. Furthermore, the study concluded that there were 7 activities that had the potential to support the outcome "The student shows awareness for phonetics" from among a total of 40 activities in the activity book of the Preschool Education Program. These results show that it is necessary to improve the activities in the Preschool Education Program in order to develop the phonetic awareness of the children who attend preschool institutions.
\end{abstract}

Key Words: Preschool education program, activity, language development, phonetic awareness.

\footnotetext{
* Doç. Dr. Uludağ Üniversitesi, Eğitim Fakültesi, Temel Eğitim Bölümü, Bursa. e-posta:hkartal@uludag.edu.tr

** Öğretmen, T.C. Lyon Eğitim Ataşeliği, Rodez/ Fransa. e-posta:fatih_guner17@hotmail.com
} 


\section{Giriş}

Illk çocukluk yılları, başarının anahtarı ve en kritik dönem olarak kabul edilmektedir. Bu dönemde çocuğa verilen destek, bireyin yaşamının tamamına etki edecek derecede önem taşımaktadır. Bu destek içerisindeki alanlardan biri de kurumsal erken çocukluk eğitimidir (Ekici, 2014; Kılıç, 2008; Pehlivan, 2006; Uyanık ve Kandır, 2010). Günümüzde okul öncesi eğitimin önemine yönelik bilincin yükselmesi, aile yapılarının geniş aile yapısından çekirdek aile yapısına dönüşmesi, çalışan anne ve çocuk merkezli yaşayan aile sayısının artması gibi nedenlerle okul öncesi eğitim kurumlarına olan gereksinimin artığı bilinmektedir (Ekici, 2014).

2013- 2014 eğitim- öğretim yılı başında güncellenen Okul Öncesi Eğitim Programı, Türkiye'deki tüm okul öncesi eğitim kurumlarında uygulanmaktadır (MEB, 2013a). Okul Öncesi Eğitim Programı (MEB, 2013a) ilerlemecilik felsefesinin benimsendiği, farklı eğitim yaklaşımlarını yansıtan ve High Scope, Montessori, Regio Emilia gibi farklı eğitim modellerinin sentezlendiği eklektik, sarmal bir programdır (Gürkan ve Koran, 2014). Programda, okul öncesi eğitim kurumlarına devam eden çocukların zengin öğrenme deneyimleri aracılığıyla sağlıklı büyümeleri, bütün gelişim alanlarının desteklenerek en üst düzeye ulaşmaları, öz bakım becerilerini kazanmaları ve temel eğitime hazırlanmaları amaçlanmaktadır (MEB, 2013a, 10).

Okulöncesi eğitimde tek başına okuma becerilerine ilişkin temellerin oluşturulmasında belirleyici olan (Stanovich, 1986) ve okuma güçlüklerinin önlenmesini sağlayan sesbilgisi farkındalığı becerilerinin desteklenmesi gerekmektedir (Cramer, 2006, 91; Acarlar, Ege ve Turan, 2002; Aktan ve Oktay, 1997; Erduran, 1999; Kerem, 2001; Sayar ve Turan, 2012; Turan ve Akoğlu, 2011; Turan ve Gül, 2008). Sesbilgisi farkındalığı, konuşma sırasında sözcüklerde yer alan sesleri fark edebilme anlamına gelmektedir (Phelps, 2003; Akt. Turan ve Gül, 2008). Sesbilgisi farkındalığı aynı zamanda çocuğun uyak ve sesleri yinelemesi, sözcükteki heceleri ve sesleri ayırması, sözcükteki hece ve sesleri birleştirmesi, konuşma dilinin farklı yollarla daha küçük bileşenlere bölünmüş olabileceğini sezmesi ve sesleri manipüle edebilmesidir (Chard \& Dickson, 1999). Çocukların okulöncesi dönemde, sözcüklerin sesbilgisel yapılarına duyarlılık gösterdikleri bilinmektedir (Roskos, Christie \& Richgelds, 2003). Sesbilgisi farkındalığı gelişiminin düşük düzeyde olmasının, okuma becerisinde karşılaşılan sorunların nedenleri arasında ilk sıralarda yer aldığı (Lane, Pullen, Eisele \& Jordan, 2002) ve sesbilgisi farkındalığının okuma çalışmaları içerisindeki önemi yapılan çalışmalarda açıkça ifade edilmektedir (Akoğlu ve Turan, 2012; Anthony \& Francis; 2005, Bayraktar, 2013; Erdoğan, 2011; Erdoğan, 2012; Güldenoğlu, Kargın ve Ergül, 2016; Karakelle, 2004; Kerem, 2001; Kesikçi ve Amado, 2005; Mc Gee \& Ukrainetz, 2009; Özcan ve Özcan, 2014; Sarı, 2012; Süel, 2011; Yücel, 2009).

Harf ve harfin işleyişi arasındaki ilişkiyi anlamak için ön koşul niteliğinde olan sesbilgisi farkındalığı becerisi (Erdoğan, 2009), sözcüklerin anlamlarından çok onların yapısı ile de ilgilidir (Hempenstall, 2003). Okul öncesi dönemde çocukların sözcük farkındalığı, hece farkındalığı, ilk ses/son 
ses farkındalığı ve fonem farkındalığı basamaklarından geçmeleri ve bu basamaklarda, fark etmebölme- harmanlama- ekleme- çıkarma- kullanma gibi görevleri gerçekleştirmeleri beklenmektedir. Bu basamaklardan geçerek gerçekleştirilmesi beklenen görevleri yerine getirmiş, sesbilgisi farkındalığı gelişmiş bir çocuğun okuma becerisini kazanmaya hazır olduğu düşünülmektedir (Chard ve Dickson, 1999; Karakelle, 1998).

Türkiye'deki Okul Öncesi Eğitim Programı́nın (MEB, 2013a, 26), dil gelişim alanındaki on iki kazanımdan bir tanesi (Kazanım 9), sesbilgisi farkındalığı ile ilgilidir. Bu kazanım programda "Sesbilgisi farkındalı̆̆ı gösterir." şeklinde ifade edilmektedir. Kazanıma ait "Sözcüklerin başlangıç seslerini söyler. Sözcüklerin sonunda yer alan sesleri söyler. Aynı sesle başlayan sözcükler üretir. Aynı sesle biten sözcükler üretir. Şiir, öykü ve tekerlemedeki uyağı söyler. Söylenen sözcükle uyaklı başka sözcükler söyler." şeklinde ifade edilen 6 gösterge bulunmaktadır. Okul Öncesi Eğitim Programı ile birlikte öğretmenin hazırlayacağı etkinlik havuzuna örnek olması amacıyla farklı yaş gruplarındaki çocuklar için “Etkinlik Örnekleri” hazırlandığı belirtilmektedir (MEB, 2013a, 14). Öğretmenlere örnek olması amacıyla hazırlanan Okul Öncesi Eğitim Programı Etkinlik Kitabı'nın (MEB, 2013b) öğretmenler tarafından geliştirilmesi istenmektedir (MEB, 2013b). Bu açıklamalar, programdaki kazanım ve göstergelerin uygulamaya geçirilmesinde hem öğretmene doğrudan sorumluluk verildiğini hem de etkinliklerin geliştirilmesi ve zenginleştirilmesinde öğretmenlerin yaratıcılıklarına gereksinim duyulduğunu göstermektedir. Fakat yapılan araştırmalar (Bay, 2008; Ergül ve ark., 2014; Karaman ve Üstün, 2011), okul öncesi öğretmenlerinin sesbilgisi farkındalığına yeterince önem ver(e)mediklerini ortaya koymaktadır.

Bu çalışmada, Okul Öncesi Eğitim Programı Etkinlik Kitabı'ndaki etkinliklerin (MEB, 2013b) sesbilgisi farkındalığı açısından incelenmesiyle elde edilecek sonuçların ve sunulacak önerilerin, öğretmenlerin okul öncesi eğitim kurumlarına devam eden çocukların sesbilgisi farkındalığı becerilerine katkı sunmalarında yol gösterici olabileceği, alanyazında bu konuda bir çalışma olmadığı gerçeği göz önüne alınarak söylenebilir. Araştırmada öncelikle, Okul Öncesi Eğitim Programı Etkinlik Kitabı'nda (MEB, 2013b) yer alan etkinliklerin "Ses bilgisi farkındalığı gösterir." kazanımı tarafından doğrudan desteklenen etkinlikler olup olmadığına yönelik tespitler yapılacaktır. Bu tespitin ardından mevcut etkinlikler arasından "Ses bilgisi farkındalığı gösterir." kazanımını destekleyebileceği düşünülen etkinlikler belirlenerek bu etkinliklerde "Ses bilgisi farkındalığı gösterir." kazanımının hangi göstergelerle gerçekleştirilebileceğine ilişkin çözümlemeler yapılacaktır. Bu kapsamda araştırmada aşağıdaki iki soruya cevap aranmaktadır.

1- Okul Öncesi Eğitim Programı Etkinlik Kitabı'nda (MEB, 2013b) “Ses bilgisi farkındalığı gösterir." kazanımının doğrudan desteklendiği etkinlik örnekleri bulunmakta mıdır? 
2- Okul Öncesi Eğitim Programı Etkinlik Kitabı'nda (MEB, 2013b) farklı kazanımları desteklemeye yönelik hazırlanan etkinlikler arasında "Ses bilgisi farkındalığı gösterir." kazanımının desteklenebileceği etkinlik örnekleri bulunmakta mıdır?

\section{Yöntem}

\section{Araştırma Modeli}

Araştırılması hedeflenen konu ile ilgili yazılı materyallerin incelendiği bu çalışma, nitel yönteme göre desenlenmiştir. Nitel araştırma, "Gözlem, görüşme ve doküman analizi gibi nitel veri toplama yöntemlerinin kullanıldığı, olguların ve olayların doğal ortamda gerçekçi ve bütüncül bir biçimde ortaya konmasına yönelik nitel bir sürecin izlendiği araştırma" şeklinde tanımlanmaktadır (Yıldırım ve Şimşek, 2008: 39).

\section{Örneklem}

Çalışmanın örneklemini, sesbilgisi farkındalığı ile ilgili kazanım, gösterge, açıklamalar ve öğrenme süreçleri doğrultusunda incelenecek olan Okul Öncesi Eğitim Programı Etkinlik Kitabı'ndaki (MEB, 2013b) etkinlik örnekleri oluşturmaktadır.

\section{Verilerin Toplanması}

Bu çalışmada, nitel araştırmalarda veri toplama yöntemi olarak kullanılan doküman incelemesi yöntemi kullanılmıştır. Araştırmada izlenen adımlar şunlardır: a) Okul Öncesi Eğitim Programı'ndaki (MEB, 2013a) sesbilgisel farkındalık kazanımının ve bu kazanımla ilgili gösterge ve açıklamaların belirlenmesi; b) Okul Öncesi Eğitim Programı Etkinlik Kitabı'ndaki (MEB, 2013b) sesbilgisi farkındalığı kazanımının ve bu kazanımla ilgili gösterge ve açıklamaların yer aldığı etkinlik örneklerinin belirlenmesi; c) Okul Öncesi Eğitim Programı Etkinlik Kitabı'ndaki (MEB, 2013b) farklı kazanımları desteklemeye yönelik hazırlanan etkinlikler arasında "Ses bilgisi farkındalığı gösterir." kazanımının desteklenebileceği etkinlik örneklerinin belirlenmesi; d) Elde edilen verilerin güvenirliğinin artırılması amacıyla verilerin bir başka alan uzmanı tarafından analiz edilmesi.

\section{Verilerin Analizi}

Çalışmada, verilerin analizinde betimsel analizden yararlanılmıştır. Betimsel analizde veriler, önceden belirlenen başlıklar altında özetlenebilmektedir. Yapılan betimlemelerden yola çıkarak, daha sonra araştırmacının kendi yorumlarını yapması ve bazı çıkarımlarda bulunması mümkündür (Yıldırım ve Şimşek, 2008: 225). Bu çalışmada veriler, araştırma sorularının doğrultusunda önceden belirlenen iki başlık altında sunulmakta ve yorumlanmaktadır.

Verilerin analizi iki aşamada gerçekleştirilmiştir. Veri analizinin ilk aşamasında, Okul Öncesi Eğitim Programı Etkinlik Kitabı'nda (MEB, 2013b) yer alan etkinlik örneklerinin “Kazanımlar ve Göstergeleri" şeklinde ifade edilen bölümlerine yönelik analizler yapılmıştır. Yapılan bu analizlerde, "Ses bilgisi farkındalığı gösterir." kazanımına ve bu kazanıma ait "Sözcüklerin başlangıç seslerini 
Okul Öncesi Eğitim Programı Etkinlik Kitabındaki Etkinliklerin Ses Bilgisi Farkındalığı Açısından İncelenmesi

söyler.", "Sözcüklerin sonunda yer alan sesleri söyler.", "Aynı sesle başlayan sözcükler üretir.”, “Aynı sesle biten sözcükler üretir.", "Şiir, öykü ve tekerlemedeki uyağı söyler.", "Söylenen sözcükle uyaklı başka sözcük söyler." şeklinde ifade edilen göstergelere yer verilmesi kriter olarak belirlenmiştir. Veri analizinin ikinci aşamasında, Okul Öncesi Eğitim Programı Etkinlik Kitabı'nda (MEB, 2013b) yer alan etkinlik örneklerinin "Öğrenme Süreci" şeklinde ifade edilen bölümlerine yönelik analizler yapılmıştır. Bu aşamada, farklı kazanımları desteklemeye yönelik hazırlanmış etkinlik örneklerinin öğrenme süreçlerinde "Ses bilgisi farkındalığı gösterir." kazanımını destekleyebilecek ifadelerin olup olmadığına ilişkin analizler yapılmıştır.

\section{Bulgular}

\section{Ses Bilgisi Farkındalığı Kazanımının Doğrudan Desteklendiği Etkinliklerin Belirlenmesine ïlişkin} Bulgular

Bu bölümde öncelikle, Okul Öncesi Eğitim Programı Etkinlik Kitabı'nda (MEB, 2013b) yer alan "Kar Yağıyor, Anlat- Dinle, Balonların Iç̧inde Ne var?, Eşli Yürüme, İ Bırakan Gemiler, Kokla Bul, Günaydın, Suya Sabuna Dokunalım, Ağır Mı Hafif Mi?, Olumlu- Olumsuz, Bahçemizi Düzenliyoruz, Bil Bakalım Hangi Top?, Bizim Çizgilerimiz, Fotoğraflarla Atatürk, Gölgemin Uzunluğu, Haydi Sınıfta Herşeyi Ölçüyoruz, Noktalama Işaretlerim, Kroki Çiziyoruz, Kurdelelerle Dans, Müze Bizi Bekler, Örüntü Oluşturuyoruz, Renk Grafiği Yapıyoruz, Taş Almaca, Bu Gölge Kimin?, Bu Ses Ne Sesi?, Buz Üzerinde, Çamurdan Çıkan Öyküler, Deneyelim, Bulalım, Kapakları Takalım, Geri Dönüşüm, Kartopu Oynuyoruz, Toprağın İ̧̧inde Neler Varmış?, Kelebekleri Kim Çizmiş?, Kitabın Kayıp Sayfaları, Kurbağa Kum Kum, Kutup Ayısı, Süt Şişesinin Yolculuğu, Say Balonları Say, Çiftlikte, iplerle Çalışma, Terzi Olsam" isimli etkinlikler arasında "Ses bilgisi farkındalığı gösterir." kazanımının doğrudan desteklendiği herhangi bir etkinlik olmadığı belirlenmiştir. Bu durum, öğretmenlerin sesbilgisi farkındalığı gelişimini destekleyecek etkinliklere yer verememelerine dolayısıyla da öğrencilerin ses bilgisi farkındalığı gelişimlerinin desteklenememesine neden olabilir.

\section{Ses Bilgisi Farkındalığı Kazanımını Destekleyebileceği Düşünülen Etkinliklere İlişkin Bulgular}

Bu başlık altında, Okul Öncesi Eğitim Programı Etkinlik Kitabı'ndaki (MEB, 2013b) farklı kazanımları desteklemeye yönelik hazırlanmış etkinliklerden "Ses bilgisi farkındalığı gösterir." kazanımını destekleyebilecek etkinlik örneklerinin olup olmadığına yönelik analizler yapılmıştır.

Okul Öncesi Eğitim Programı Etkinlik Kitabı'ndaki (MEB, 2013b) 40 etkinlikten dil gelişim alanının "Ses bilgisi farkındalı̆ı̆ gösterir." kazanımını ve bu kazanıma ait göstergeleri (Sözcüklerin başlangıç seslerini söyler. Sözcüklerin sonunda yer alan sesleri söyler. Aynı sesle başlayan sözcükler üretir. Aynı sesle biten sözcükler üretir. Şiir, öykü ve tekerlemedeki uyağı söyler. Söylenen sözcükle 
uyaklı başka sözcük söyler.) destekleyebileceği düşünülen 7 etkinliğe ait bulgular etkinlik numaraları göz önüne alınarak sırası ile aşağıda sunulmaktadır.

Tablo 1. "Günaydın" İsimli Etkinliğe iliş̧kin Bulgular

\begin{tabular}{|c|c|c|c|c|c|c|}
\hline \multirow[t]{2}{*}{ Öğrenme süreci } & \multicolumn{2}{|c|}{$\begin{array}{l}\text { Aynı sesle başlayan } \\
\text { sözcükler üretir. }\end{array}$} & \multicolumn{2}{|c|}{$\begin{array}{l}\text { Aynı sesle biten } \\
\text { sözcükler üretir. }\end{array}$} & \multicolumn{2}{|c|}{$\begin{array}{l}\text { Söylenen sözcükle uyaklı } \\
\text { başka sözcük söyler. }\end{array}$} \\
\hline & $\begin{array}{l}\text { Yönergede } \\
\text { geçen }\end{array}$ & $\begin{array}{l}\text { Çocuğun } \\
\text { söyleye- } \\
\text { bileceği }\end{array}$ & $\begin{array}{l}\text { Yönergede } \\
\text { geçen }\end{array}$ & $\begin{array}{l}\text { Çocuğun } \\
\text { söyleye- } \\
\text { bileceği }\end{array}$ & $\begin{array}{l}\text { Yönergede } \\
\text { geçen }\end{array}$ & $\begin{array}{l}\text { Çocuğun } \\
\text { söyleye- } \\
\text { bileceği }\end{array}$ \\
\hline $\begin{array}{l}\text { Toprak evde kimler } \\
\text { varmıs. Buradan bir } \\
\text { solucan çımış. } \\
\text { Buradan da bir tırtı. } \\
\text { İşte ben de geldim } \\
\text { demiş karınca. Hepsi } \\
\text { birden gerinmiş. } \\
\text { Birbirlerine günaydın } \\
\text { demiş. Geç uyanan } \\
\text { köstebek ben de } \\
\text { varım ben de varım } \\
\text { demiş... (MEB, 2013b, } \\
\text { 24). }\end{array}$ & $\begin{array}{l}\text { Toprak } \\
\text { Evde } \\
\text { kimler } \\
\text { varmış- } \\
\text { buradan } \\
\text { solucan } \\
\text { çıkmış } \\
\text { işte } \\
\text { gelmiş } \\
\text { demiş } \\
\text { karınca } \\
\text { hepsi } \\
\text { gerinmiş } \\
\text { uyanan } \\
\end{array}$ & $\begin{array}{l}\text { Tepsi } \\
\text { etek } \\
\text { kirpi } \\
\text { vermiş } \\
\text { bilmece } \\
\text { salyangoz } \\
\text { çokmuş } \\
\text { ikiz } \\
\text { gitmiş } \\
\text { dondurma } \\
\text { kadar } \\
\text { hediye } \\
\text { güzelmiş } \\
\text { unutmak } \\
\end{array}$ & $\begin{array}{l}\text { toprak } \\
\text { evde } \\
\text { kimler } \\
\text { varmış } \\
\text { buradan } \\
\text { tırtıl } \\
\text { geldim } \\
\text { karınca } \\
\text { hepsi } \\
\text { geç }\end{array}$ & $\begin{array}{l}\begin{array}{l}\text { kumbara } \\
\text { eğer }\end{array} \\
\text { renkler } \\
\text { şapka } \\
\text { nasıl } \\
\text { lastik } \\
\text { mum } \\
\text { atla } \\
\text { ikinci } \\
\text { çabuk }\end{array}$ & $\begin{array}{l}\text { varmış } \\
\text { çıkmış } \\
\text { demiş } \\
\text { gerinmiş }\end{array}$ & $\begin{array}{l}\text { sarmış } \\
\text { sıkmış } \\
\text { yemiş } \\
\text { derinmiş }\end{array}$ \\
\hline
\end{tabular}

Etkinlik çeşidi olarak Türkçe ve Oyun (Bütünleştirilmiş Büyük Grup Etkinliği) grubunda yer alan "Günaydın" isimli etkinlik 36- 48 ay grubuna yöneliktir. Etkinlikle "Nesne/durum/olaya dikkatini verir (bilişsel gelişim). Sesini uygun kullanır (dil gelişimi). Yer değiştirme hareketleri yapar (motor gelişim). Bir olay ya da durumla ilgili olarak başkalarının duygularını açıklar (motor gelişim), kazanımlarının gerçekleştirilmesi amaçlanmaktadır (MEB, 2013b, 24). Bu kazanımların yanı sıra etkinlikte, çocukların "aynı sesle başlayan sözcükler üretmeleri, aynı sesle biten sözcükler üretmeleri ve söylenen sözcükle uyaklı başka sözcük söylemeleri" sağlanabilir. Ayrıca sözcüklerin başlangıç seslerinin " $t, e, k, v, b, s, c, i, g, d, k, h$ ", söylenmesi, sözcük sonlarında yer alan seslerin " $k, e, r, s, n, a, l, m, i, v, b$. " söylenmesi ve uyakların "mış, miş" söylenmesi sağlanarak okul öncesi dönemdeki çocukların ses bilgisi farkındalığı gelişimleri desteklenebilir. 
Tablo 2. "Olumlu Olumsuz" Isimli Etkinliğe ilişskin Bulgular

\begin{tabular}{|c|c|c|c|c|c|c|}
\hline \multirow[b]{2}{*}{ Öğrenme süreci } & \multicolumn{2}{|c|}{$\begin{array}{l}\text { Aynı sesle başlayan } \\
\text { sözcükler üretir. }\end{array}$} & \multicolumn{2}{|c|}{$\begin{array}{l}\text { Aynı sesle biten } \\
\text { sözcükler üretir. }\end{array}$} & \multicolumn{2}{|c|}{$\begin{array}{l}\text { Söylenen sözcükle } \\
\text { uyaklı başka sözcük } \\
\text { söyler. }\end{array}$} \\
\hline & $\begin{array}{l}\text { Yönergede } \\
\text { geçen }\end{array}$ & $\begin{array}{l}\text { Çocuğun } \\
\text { söyleye- } \\
\text { bileceği }\end{array}$ & $\begin{array}{l}\text { Yönergede } \\
\text { geçen }\end{array}$ & $\begin{array}{l}\text { Çocuğun } \\
\text { söyleye- } \\
\text { bileceği }\end{array}$ & $\begin{array}{l}\text { Yönergede } \\
\text { geçen }\end{array}$ & $\begin{array}{l}\text { Çocuğun } \\
\text { söyleye- } \\
\text { bileceği }\end{array}$ \\
\hline $\begin{array}{l}\text { Bir dairenin içine "ayna", } \\
\text { "ağaç", "at", "ayakkabı", } \\
\text { "ayı", "arı", diğer dairenin } \\
\text { içine ise "elma", "etek", } \\
\text { "el”, "eldiven", "ev", } \\
\text { "elbise" fotoğrafları konur. } \\
\text { Her fotoğraf gösterilerek } \\
\text { resimdeki görselin adı } \\
\text { söylenir... } \\
\text { (MEB, 2013b, 30). }\end{array}$ & $\begin{array}{l}\text { ayna } \\
\text { ağaç } \\
\text { at } \\
\text { ayakkabı } \\
\text { ayı } \\
\text { arı } \\
\text { elma } \\
\text { etek } \\
\text { el } \\
\text { eldiven }\end{array}$ & $\begin{array}{l}\text { arka } \\
\text { askı } \\
\text { al } \\
\text { açık, } \\
\text { akşam, } \\
\text { az } \\
\text { erik } \\
\text { eşek } \\
\text { eş } \\
\text { eski }\end{array}$ & $\begin{array}{l}\text { ayna } \\
\text { ağaç } \\
\text { at } \\
\text { ayakkabı } \\
\text { ayı } \\
\text { arı } \\
\text { elma } \\
\text { etek } \\
\text { el } \\
\text { eldiven }\end{array}$ & $\begin{array}{l}\text { adım } \\
\text { çilek } \\
\text { top } \\
\text { ılık } \\
\text { Islık } \\
\text { Islak } \\
\text { ayran } \\
\text { kedi } \\
\text { lamba } \\
\text { nar }\end{array}$ & $\begin{array}{l}\text { ayna } \\
\text { ağaç } \\
\text { at } \\
\text { ayakkabı } \\
\text { elma } \\
\text { etek } \\
\text { el } \\
\text { eldiven } \\
\text { ev } \\
\text { elbise }\end{array}$ & $\begin{array}{l}\text { oyna } \\
\text { topaç } \\
\text { kat } \\
\text { sarı } \\
\text { asma } \\
\text { yelek } \\
\text { sel } \\
\text { merdiven } \\
\text { ov } \\
\text { gelirse }\end{array}$ \\
\hline
\end{tabular}

Etkinlik çeşidi olarak Türkçe (Büyük- Küçük Grup Etkinliği) grubunda yer alan “Olumlu Olumsuz" isimli etkinlik, 48- 72 ay grubuna yöneliktir. Etkinlikle dil gelişimi alanında "Sesleri ayırt eder.", "Söz dizimi kurallarına göre cümle kurar." ve "Konuşurken dilbilgisi yapılarını kullanır." kazanımları ve motor gelişim alanında ise "Yer değiştirme hareketleri yapar." kazanımlarının gerçekleştirilmesi amaçlanmaktadır (MEB, 2013b, 30). Ayrıca bu etkinlikte yer verilen görsel unsurların sözcük olarak karşııklarının söylenmesiyle çocukların "aynı sesle başlayan sözcükler üretmeleri, aynı sesle biten sözcükler üretmeleri ve söylenen sözcükle uyaklı başka sözcük söylemeleri” sağlanabileceği gibi bu sözcüklerin başlangıç seslerinin " $a, e$ " söylenmesi ve sözcüklerin sonunda yer alan seslerin " $a, c, t, ı, k, l, n, v, e$ " söylenmesi sağlanarak okul öncesi dönemdeki çocukların ses bilgisi farkındalığı gelişimleri bu göstergeler açısından desteklenebilir. 
Tablo 3. "Bahçemizi Düzenliyoruz" Isimli Etkinliğe ilişkin Bulgular

\begin{tabular}{|c|c|c|c|c|c|c|}
\hline \multirow[t]{2}{*}{ Öğrenme süreci } & \multicolumn{2}{|c|}{$\begin{array}{l}\text { Aynı sesle başlayan } \\
\text { sözcükler üretir. }\end{array}$} & \multicolumn{2}{|c|}{$\begin{array}{l}\text { Aynı sesle biten } \\
\text { sözcükler üretir. }\end{array}$} & \multicolumn{2}{|c|}{$\begin{array}{l}\text { Söylenen sözcükle } \\
\text { uyaklı başka sözcük } \\
\text { söyler. }\end{array}$} \\
\hline & $\begin{array}{l}\text { Şiirde } \\
\text { geçen }\end{array}$ & $\begin{array}{l}\text { Çocuğun } \\
\text { söyleye- } \\
\text { bileceği }\end{array}$ & $\begin{array}{l}\text { Şiirde } \\
\text { geçen }\end{array}$ & $\begin{array}{l}\text { Çocuğun } \\
\text { söyleye- } \\
\text { bileceği }\end{array}$ & $\begin{array}{l}\text { Şiirde } \\
\text { geçen }\end{array}$ & $\begin{array}{l}\text { Çocuğun } \\
\text { söyleye- } \\
\text { bileceği }\end{array}$ \\
\hline $\begin{array}{l}\text { Nasıl Bir Bahçem Olsa } \\
\text { Yemyeşil ağaçlar olsa, } \\
\text { Kuşlar kelebekler uçsa, } \\
\text { Gelip omzuma konsa, } \\
\text { Böyle de bir bahçem olsa, } \\
\text { Masmavi bir havuz olsa, } \\
\text { Renk renk balıklarla dolsa, } \\
\text { Hep beraber oynasalar, } \\
\text { Böyle de bir bahçem olsa. } \\
\text { Salıncakta çocuklar, } \\
\text { Kaydıraktan kayarlar, } \\
\text { Kumlarla oynuyorlar, } \\
\text { Böyle de bir bahçem olsa... } \\
\text { (MEB, 2013b, 32). }\end{array}$ & $\begin{array}{l}\text { yemyeşil } \\
\text { ağaçlar } \\
\text { olsa } \\
\text { kuşlar } \\
\text { uçsa } \\
\text { gelip } \\
\text { böyle } \\
\text { masmavi } \\
\text { havuz } \\
\text { renk } \\
\text { dolsa } \\
\text { hep } \\
\text { salıncakta }\end{array}$ & $\begin{array}{l}\text { yaş } \\
\text { amca } \\
\text { ot } \\
\text { kuzu } \\
\text { uçurtma } \\
\text { gitti } \\
\text { burun } \\
\text { mutlu } \\
\text { havuç } \\
\text { reçel } \\
\text { dolma } \\
\text { herkes } \\
\text { saklambaç }\end{array}$ & $\begin{array}{l}\text { yemyeşil } \\
\text { ağaçlar } \\
\text { olsa } \\
\text { gelip } \\
\text { böyle } \\
\text { bahçem } \\
\text { masmavi } \\
\text { havuz } \\
\text { renk } \\
\text { kaydıraktan }\end{array}$ & $\begin{array}{l}\text { lale } \\
\text { rende } \\
\text { asker } \\
\text { pasta } \\
\text { evcil } \\
\text { masa } \\
\text { iki } \\
\text { zarf } \\
\text { kalp } \\
\text { neden }\end{array}$ & $\begin{array}{l}\text { olsa } \\
\text { uçsa } \\
\text { konsa } \\
\text { oynasalar } \\
\text { çocuklar } \\
\text { kayarlar } \\
\text { oynuyorlar }\end{array}$ & $\begin{array}{l}\text { dolsa } \\
\text { kaçsa } \\
\text { koşsa } \\
\text { hoplasalar } \\
\text { kuşlar } \\
\text { sayarlar } \\
\text { soyuyorlar }\end{array}$ \\
\hline
\end{tabular}

Etkinlik çeşidi olarak Sanat ve Müzik (Bütünleştirilmiş Büyük-Küçük Grup Etkinliği) grubunda yer alan "Bahçemizi Düzenliyoruz" isimli etkinlik, 60- 72 ay grubuna yöneliktir. Etkinlikle üç gelişim alanında dört kazanımın gerçekleştirilmesi amaçlanmaktadır. Bunlar dil gelişimi alanında "Dinlediklerini/ izlediklerini çeşitli yollarla ifade eder.", "Görsel materyalleri okur.", motor gelişim alanında "Müzik ve ritim ve eşliğinde hareket eder." ve sosyal- duygusal gelişim alanında ise "Estetik değerleri korur." kazanımlarıdır (MEB, 2013b, 32).

Etkinlikte yer alan "Nasıl Bir Bahçem Olsa” isimli şiirle çocukların "aynı sesle başlayan sözcükler üretmeleri, aynı sesle biten sözcükler üretmeleri ve söylenen sözcükle uyaklı başka sözcük söylemeleri” sağlanabileceği gibi etkinlikteki şiirde bulunan sözcüklerin başlangıç seslerinin

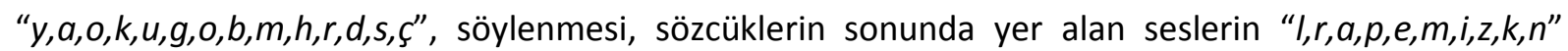
söylenmesi ve şiirdeki uyakların "sa, lar" söylenmesi sağlanarak okul öncesi dönemdeki çocukların ses bilgisi farkındalığının tüm göstergeleri açııından gelişimleri desteklenebilir. 
Tablo 4. "Müze Bizi Bekler" Isimli Etkinliğe ilişkin Bulgular

\begin{tabular}{|c|c|c|c|c|c|c|}
\hline \multirow[t]{2}{*}{ Öğrenme süreci } & \multicolumn{2}{|c|}{$\begin{array}{l}\text { Aynı sesle başlayan } \\
\text { sözcükler üretir. }\end{array}$} & \multicolumn{2}{|c|}{$\begin{array}{l}\text { Aynı sesle biten } \\
\text { sözcükler üretir. }\end{array}$} & \multicolumn{2}{|c|}{$\begin{array}{l}\text { Söylenen sözcükle } \\
\text { uyaklı başka } \\
\text { sözcük söyler. }\end{array}$} \\
\hline & $\begin{array}{l}\text { Şiirde } \\
\text { geçen }\end{array}$ & $\begin{array}{l}\text { Çocuğun } \\
\text { söyleye- } \\
\text { bileceği }\end{array}$ & $\begin{array}{l}\text { Şiirde } \\
\text { geçen }\end{array}$ & $\begin{array}{l}\text { Çocuğun } \\
\text { söyleye- } \\
\text { bileceği }\end{array}$ & $\begin{array}{l}\text { Şiirde } \\
\text { geçen }\end{array}$ & $\begin{array}{l}\text { Çocuğun } \\
\text { söyleye- } \\
\text { bileceği }\end{array}$ \\
\hline $\begin{array}{l}\text { Müze } \\
\text { Müzeler bizim için, haydi gidip gezelim, } \\
\text { Eskiden kalmış eserleri tek tek görelim, } \\
\text { Hepsi de çok önemli, kıymetini bilelim, } \\
\text { Müzelere gidelim, ilginç şeyler görelim. } \\
\text { (MEB, 2013b, 50). }\end{array}$ & $\begin{array}{l}\text { müzeler } \\
\text { bizim } \\
\text { için } \\
\text { haydi } \\
\text { gidip } \\
\text { eskiden } \\
\text { kalmış } \\
\text { eserleri } \\
\text { tek } \\
\text { çok } \\
\text { önemli } \\
\text { şeyler }\end{array}$ & $\begin{array}{l}\text { mandalina } \\
\text { büyük } \\
\text { içecek } \\
\text { havuç } \\
\text { gelip } \\
\text { ekşi } \\
\text { kar } \\
\text { eldiven } \\
\text { top } \\
\text { çanta } \\
\text { ördek } \\
\text { şarkı }\end{array}$ & $\begin{array}{l}\text { müzeler } \\
\text { bizim } \\
\text { için } \\
\text { haydi } \\
\text { gidip } \\
\text { gezelim } \\
\text { eskiden } \\
\text { kalmış } \\
\text { tek } \\
\text { müzelere } \\
\text { ilginç }\end{array}$ & $\begin{array}{l}\text { robot } \\
\text { musluk } \\
\text { nar } \\
\text { inek } \\
\text { pırasa } \\
\text { mantar } \\
\text { neden } \\
\text { şekil } \\
\text { kelebek } \\
\text { etek } \\
\text { çünkü }\end{array}$ & $\begin{array}{l}\text { için } \\
\text { gezelim } \\
\text { eserleri } \\
\text { görelim } \\
\text { önemli } \\
\text { bilelim } \\
\text { gidelim } \\
\text { görelim }\end{array}$ & $\begin{array}{l}\text { seçin } \\
\text { çizelim } \\
\text { yerleri } \\
\text { gidelim } \\
\text { bahçeli } \\
\text { görelim } \\
\text { gelelim } \\
\text { gezelim }\end{array}$ \\
\hline
\end{tabular}

Etkinlik çeşidi olarak Türkçe ve Alan Gezisi (Bütünleştirilmiş Büyük Grup Etkinliği) grubunda yer alan "Müze Bizi Bekler" isimli etkinlik, 60- 72 ay grubuna yöneliktir. Etkinlikle dil gelişimi alanında "Söz dizimi kurallarına göre cümle kurar." ve "Konuşurken dilbilgisi yapılarını kullanır."; sosyal-duygusal gelişim alanında ise "Kendini yaratıcı yollarla ifade eder.", "Değişik ortamlardaki kurallara uyar." ve "Sanat eserlerinin değerini fark eder." kazanımlarının gerçekleştirilmesi amaçlanmaktadır (MEB, 2013b, 50).

Etkinlikteki "Müze” isimli şiirin sözleri aracılığıyla çocukların "aynı sesle başlayan sözcükler üretmeleri, aynı sesle biten sözcükler üretmeleri ve söylenen sözcükle uyaklı başka sözcük söylemeleri” sağlanabileceği gibi etkinlikteki şiirde bulunan sözcüklerin başlangıç seslerinin " $m, b, i, h, g, e, k, t, c, \ddot{o}, k, i, s$ ", $^{\circ}$ söylenmesi sözcüklerin sonunda yer alan seslerin " $r, m, n, i, p, m, s, k, e, c^{\prime}$ " söylenmesi ve şiirdeki uyağın "lim" söylenmesi sağlanarak okul öncesi dönemdeki çocukların ses bilgisi farkındalığının tüm göstergeleri açısından gelişimleri desteklenebilir.

Tablo 5. "Deneyelim, Bulalım, Kapakları Takalım" İsimli Etkinliğe ilişsin Bulgular

\begin{tabular}{|c|c|c|c|c|c|c|}
\hline \multirow[b]{2}{*}{ Öğrenme süreci } & \multicolumn{2}{|c|}{$\begin{array}{l}\text { Aynı sesle başlayan } \\
\text { sözcükler üretir. }\end{array}$} & \multicolumn{2}{|c|}{$\begin{array}{l}\text { Aynı sesle biten } \\
\text { sözcükler üretir. }\end{array}$} & \multicolumn{2}{|c|}{$\begin{array}{l}\text { Söylenen sözcükle } \\
\text { uyaklı başka sözcük } \\
\text { söyler. }\end{array}$} \\
\hline & $\begin{array}{l}\text { Şiirde } \\
\text { geçen }\end{array}$ & $\begin{array}{l}\text { Çocuğun } \\
\text { söyleye- } \\
\text { bileceği }\end{array}$ & $\begin{array}{l}\text { Şiirde } \\
\text { geçen }\end{array}$ & $\begin{array}{l}\text { Çocuğun } \\
\text { söyleye- } \\
\text { bileceği }\end{array}$ & $\begin{array}{l}\text { Şiirde } \\
\text { geçen }\end{array}$ & $\begin{array}{l}\text { Çocuğun } \\
\text { söyleye- } \\
\text { bileceği }\end{array}$ \\
\hline $\begin{array}{l}\text { Çevir Çevir Öyle Tak } \\
\text { Kapakları alalım kavanoza takalım, } \\
\text { Eğer ona uymazsa şişelere bakalım. } \\
\text { Dene dene bul işte, }\end{array}$ & $\begin{array}{l}\text { kapakları } \\
\text { alalım } \\
\text { kavanoza } \\
\text { takalım } \\
\text { eğer }\end{array}$ & $\begin{array}{l}\text { kalem } \\
\text { ayva } \\
\text { kartal } \\
\text { toka } \\
\text { esinti }\end{array}$ & $\begin{array}{l}\text { kapakları } \\
\text { alalım } \\
\text { kavanoza } \\
\text { eğer } \\
\text { şişelere }\end{array}$ & $\begin{array}{l}\text { Izgara } \\
\text { mandal } \\
\text { arı } \\
\text { raket } \\
\text { enginar }\end{array}$ & $\begin{array}{l}\text { alalım } \\
\text { bakalım } \\
\text { işte } \\
\text { nereye } \\
\text { tak }\end{array}$ & $\begin{array}{l}\text { yapalım } \\
\text { çakalım } \\
\text { enişte } \\
\text { dereye } \\
\text { çak }\end{array}$ \\
\hline
\end{tabular}




\begin{tabular}{|c|c|c|c|c|c|c|}
\hline $\begin{array}{l}\text { Hangi kapak nereye, } \\
\text { Çevir çevir öyle tak, } \\
\text { Bulamazsan yine bak. } \\
\qquad \text { (MEB, 2013b, 66). }\end{array}$ & $\begin{array}{l}\text { ona } \\
\text { uymazsa } \\
\text { şişelere } \\
\text { bakalım } \\
\text { dene } \\
\text { işte } \\
\text { hangi } \\
\text { nereye } \\
\text { çevir } \\
\text { öyle } \\
\text { yine }\end{array}$ & $\begin{array}{l}\text { onun } \\
\text { unutma } \\
\text { şirin } \\
\text { bul } \\
\text { dergi } \\
\text { ise } \\
\text { harika } \\
\text { nasıl } \\
\text { çam } \\
\text { önde } \\
\text { yaprak }\end{array}$ & $\begin{array}{l}\text { bul } \\
\text { hangi } \\
\text { kapak } \\
\text { bulamazsan }\end{array}$ & $\begin{array}{l}\text { lira } \\
\text { icat } \\
\text { kartal } \\
\text { nerede }\end{array}$ & bak & tak \\
\hline
\end{tabular}

Etkinlik çeşidi olarak Matematik (Büyük Grup Etkinliği) grubunda yer alan “Deneyelim Bulalım, Kapakları Takalım" isimli etkinlik, 48- 72 ay grubuna yöneliktir. Etkinlikle bilişsel gelişiminin yanı sıra motor gelişim alanında bir kazanımın gerçekleştirilmesi amaçlanmaktadır. Bunlar bilişsel gelişim alanında "Nesne ya da varlıkları gözlemler.", "Nesne ya da varlıkları özelliklerine göre eşleştirir.", “Nesne ya da varlıkların özelliklerini karşılaştırır." ve "Nesne ya da varlıkları özelliklerine göre sıralar."; motor gelişim alanında ise "Küçük kas kullanımı gerektiren hareketleri yapar." kazanımlarıdır (MEB, 2013b, 66).

Etkinlikteki "Çevir Çevir Öyle Tak" isimli şiirin sözleri aracılığıyla çocukların "aynı sesle başlayan sözcükler üretmeleri, aynı sesle biten sözcükler üretmeleri ve söylenen sözcükle uyaklı başka sözcük söylemeleri" sağlanabileceği gibi etkinlikteki şiirde bulunan sözcüklerin başlangıç seslerinin

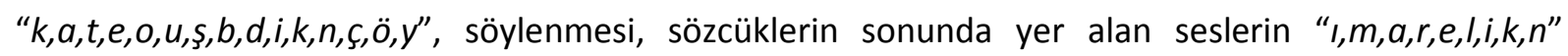
söylenmesi ve şiirdeki uyakların "Iım, $a k^{\prime}$ " söylemesi sağlanarak okul öncesi dönemdeki çocukların ses bilgisi farkındalığının tüm göstergeleri açısından gelişimleri desteklenebilir.

Tablo 6. "Kurbağa Kumkum" Isimli Etkinliğe ilişin Bulgular

\begin{tabular}{|c|c|c|c|c|c|c|}
\hline \multirow{2}{*}{ Öğrenme süreci } & \multicolumn{2}{|c|}{$\begin{array}{l}\text { Aynı sesle başlayan } \\
\text { sözcükler üretir. }\end{array}$} & \multicolumn{2}{|c|}{$\begin{array}{l}\text { Aynı sesle biten } \\
\text { sözcükler üretir. }\end{array}$} & \multicolumn{2}{|c|}{$\begin{array}{l}\text { Söylenen sözcükle uyaklı } \\
\text { başka sözcük söyler. }\end{array}$} \\
\hline & $\begin{array}{l}\text { Öyküde } \\
\text { geçen }\end{array}$ & $\begin{array}{l}\text { Çocuğun } \\
\text { söyleye- } \\
\text { bileceği }\end{array}$ & $\begin{array}{l}\text { Öyküde } \\
\text { geçen }\end{array}$ & $\begin{array}{l}\text { Çocuğun } \\
\text { söyleye- } \\
\text { bileceği }\end{array}$ & $\begin{array}{l}\text { Öyküde } \\
\text { geçen }\end{array}$ & $\begin{array}{l}\text { Çocuğun } \\
\text { söyleye- } \\
\text { bileceği }\end{array}$ \\
\hline $\begin{array}{l}\text { Kurbağa Kumkum } \\
\text { Bir zamanlar birçok hayvanın } \\
\text { bir arada yaşadığı bir orman } \\
\text { varmış... Her gün akşama } \\
\text { kadar birlikte türlü türlü } \\
\text { oyunlar oynarlarmış. Bazen } \\
\text { aralarında tatsızlıklar da } \\
\text { çıkarmış tabii... Günlerden bir } \\
\text { gün, ormanda bütün yavru } \\
\text { hayvanlar yine birlikte } \\
\text { oynuyorlarmış...Ama Kurbağa } \\
\text { Kumkum istememiş,zıplama } \\
\text { yarışının sanki nesi varmış... }\end{array}$ & $\begin{array}{l}\text { bir- } \\
\text { zamanlar } \\
\text { hayvanın } \\
\text { arada } \\
\text { yaşadığı } \\
\text { orman } \\
\text { varmış } \\
\text { tüm } \\
\text { çok } \\
\text { istediği } \\
\text { günlerden } \\
\text { kurbağa } \\
\text { çünkü } \\
\text { etmişler }\end{array}$ & $\begin{array}{l}\text { baş } \\
\text { zor } \\
\text { hava } \\
\text { arasında } \\
\text { yaşlı } \\
\text { oda } \\
\text { vermiş } \\
\text { tamam } \\
\text { çekirdek } \\
\text { izlemek } \\
\text { gemi } \\
\text { kaplumba } \\
\text { ğa } \\
\text { çatı }\end{array}$ & $\begin{array}{l}\text { bir } \\
\text { birçok } \\
\text { hayvanın } \\
\text { arada } \\
\text { varmış } \\
\text { bu } \\
\text { kumkum } \\
\text { yine } \\
\text { çünkü } \\
\text { benzesey } \\
\text { di } \\
\text { hep } \\
\text { etrafını } \\
\text { fil }\end{array}$ & $\begin{array}{l}\text { kir } \\
\text { kuru } \\
\text { nar } \\
\text { arkada } \\
\text { şaşkın } \\
\text { uçak } \\
\text { makine } \\
\text { eksik } \\
\text { ütü } \\
\text { inmek } \\
\text { posta } \\
\text { ırmak } \\
\text { leylek } \\
\text { fındık }\end{array}$ & $\begin{array}{l}\text { varmış } \\
\text { oynarlarmış } \\
\text { edermiş } \\
\text { Kumkum } \\
\text { Zumzum } \\
\text { Tomtom } \\
\text { sıkılmış } \\
\text { kenarına } \\
\text { benzeseydi } \\
\text { istiyormuş } \\
\text { düşünmüş }\end{array}$ & $\begin{array}{l}\text { çıkarmış } \\
\text { arkadaşlarmış } \\
\text { istermiş } \\
\text { Zumzum } \\
\text { Fumfum } \\
\text { Şamşam } \\
\text { kalmamış } \\
\text { yarışına- } \\
\text { isteselerdi } \\
\text { koşuyormuş } \\
\text { üşümüş }\end{array}$ \\
\hline
\end{tabular}




\begin{tabular}{|c|c|c|c|c|}
\hline $\begin{array}{l}\text { Diğer yavrular tavşan ile } \\
\text { birlikte başlayınca koşu } \\
\text { yarışına, bizimki söylene } \\
\text { söylene yerleşmiş bir dere } \\
\text { kenarına... Birazdan bir } \\
\text { kalabalık sarmış etrafını. Ama } \\
\text { o da ne?..." } \\
\text { (MEB, 2013b, 78). }\end{array}$ & $\begin{array}{l}\text { zıplama } \\
\text { önermiş } \\
\text { sanki } \\
\text { nesi } \\
\text { diğer } \\
\text { uyan } \\
\text { fil } \\
\text { öf } \\
\text { şempanze } \\
\text { meğer }\end{array}$ & $\begin{array}{l}\text { eşmek } \\
\text { zor } \\
\text { ötmek } \\
\text { senin } \\
\text { nehir } \\
\text { diş } \\
\text { uyku } \\
\text { fare } \\
\text { önde } \\
\text { şiir }\end{array}$ & $\begin{array}{l}\text { öf } \\
\text { oh }\end{array}$ & hortum \\
\hline
\end{tabular}

Etkinlik çeşidi olarak Türkçe (Büyük Grup Etkinliği) grubunda yer alan “Kurbağa Kumkum” isimli etkinlik, 36- 72 ay grubuna yöneliktir. Etkinlikle dil gelişimi alanında "Dili iletişim amacıyla kullanır."; sosyal-duygusal gelişim alanında ise "Bir olay ya da durumla ilgili olarak başkalarının duygularını açıklar." ve "Farklılıklara saygı gösterir." kazanımlarının gerçekleştirilmesi amaçlanmaktadır (MEB, 2013b, 78).

"Kurbağa Kumkum" isimli etkinlik aracılığıyla çocukların "aynı sesle başlayan sözcükler üretmeleri, aynı sesle biten sözcükler üretmeleri ve söylenen sözcükle uyaklı başka sözcük söylemeleri” sağlanabileceği gibi etkinlikte bulunan sözcüklerin başlangıç seslerinin " $b, z, h, a, y, o, v, t, c, i, g, k, c, e, z, \ddot{o}, s, n, d, u, f, \ddot{o}, s, m, v$ ”, söylenmesi sözcüklerin sonunda yer alan seslerin " $r, k, n, a, s, u, m, e, u ̈, i, p, ı, l, f, h$ ” söylenmesi ve uyakların "mıs,miş,na,di, $m$ " söylenmesi sağlanarak okul öncesi dönemdeki çocukların ses bilgisi farkındalığının göstergeleri açısından gelişimleri desteklenebilir.

Tablo 7. "Kutup Ayısı" İsimli Etkinliğe illişkin Bulgular

\begin{tabular}{|c|c|c|c|c|c|c|}
\hline \multirow{2}{*}{ Öğrenme süreci } & \multicolumn{2}{|c|}{$\begin{array}{l}\text { Aynı sesle başlayan } \\
\text { sözcükler üretir. }\end{array}$} & \multicolumn{2}{|c|}{$\begin{array}{l}\text { Aynı sesle biten } \\
\text { sözcükler üretir. }\end{array}$} & \multicolumn{2}{|c|}{$\begin{array}{l}\text { Söylenen sözcükle uyaklı } \\
\text { başka sözcük söyler. }\end{array}$} \\
\hline & $\begin{array}{l}\text { Öyküde } \\
\text { geçen }\end{array}$ & $\begin{array}{l}\text { Çocuğun } \\
\text { söyleye- } \\
\text { bileceği }\end{array}$ & $\begin{array}{l}\text { Öyküde } \\
\text { geçen }\end{array}$ & $\begin{array}{l}\text { Çocuğun } \\
\text { söyleye- } \\
\text { bileceği }\end{array}$ & $\begin{array}{l}\text { Öyküde } \\
\text { geçen }\end{array}$ & $\begin{array}{l}\text { Çocuğun } \\
\text { söyleye- } \\
\text { bileceği }\end{array}$ \\
\hline $\begin{array}{l}\text { Öğretmen... öyküyü başlatır: } \\
\text { “Kutuplarda hava ısınmış, } \\
\text { Isınmış, ısınmış... Kutup } \\
\text { ayılarının evi olan kocaman } \\
\text { buz dağları erimiş erimiş } \\
\text { erimiş ve buz dağları küçük } \\
\text { tabakalara bölünmüş, } \\
\text { bölünmüş, bölünmüş... } \\
\text { Kutup ayısının üzerinde } \\
\text { olduğu küçük buz tabakası } \\
\text { da başlamış yüzmeye......" } \\
\text { (MEB, 2013b, 80). }\end{array}$ & $\begin{array}{l}\text { kutuplarda } \\
\text { hava } \\
\text { ısınmış } \\
\text { ayılarının } \\
\text { evi } \\
\text { olan } \\
\text { buz } \\
\text { dağları } \\
\text { ve } \\
\text { tabakası } \\
\text { üzerinde } \\
\text { yüzmeye }\end{array}$ & $\begin{array}{l}\text { kutu } \\
\text { havlu } \\
\text { Islak } \\
\text { nereden } \\
\text { elbise } \\
\text { okul } \\
\text { balık } \\
\text { dereleri } \\
\text { vida } \\
\text { tuz } \\
\text { üşümek } \\
\text { yağmur }\end{array}$ & $\begin{array}{l}\text { kutuplarda } \\
\text { Isınmış } \\
\text { kutup } \\
\text { ayılarının } \\
\text { evi } \\
\text { buz } \\
\text { dağları } \\
\text { üzerinde } \\
\text { küçük } \\
\text { olduğu }\end{array}$ & $\begin{array}{l}\text { alt } \\
\text { şahin } \\
\text { parlak } \\
\text { nesne } \\
\text { iz } \\
\text { zil } \\
\text { llık } \\
\text { ebe } \\
\text { kalın } \\
\text { uzun }\end{array}$ & $\begin{array}{l}\text { Isınmış } \\
\text { erimiş } \\
\text { bölünmüş }\end{array}$ & $\begin{array}{l}\text { yıkanmış } \\
\text { tükenmiş } \\
\text { süzülmüşs }\end{array}$ \\
\hline
\end{tabular}

Etkinlik çeşidi olarak Türkçe ve Sanat (Bütünleştirilmiş Büyük- Küçük Grup Etkinliği) grubunda yer alan "Kutup Ayısı" isimli etkinlik, 48- 72 ay grubuna yöneliktir. Etkinlikle üç gelişim alanında beş kazanımın gerçekleştirilmesi amaçlanmaktadır. Bunlar bilişsel gelişim alanında "Nesne/durum/olaya 
dikkatini verir.", "Nesne/durum/olayla ilgili tahminde bulunur.", "Neden- sonuç ilişkisi kurar."; dil gelişimi alanında "Dili iletişim amacıyla kullanır." ve motor gelişim alanında ise "Küçük kas kullanımı gerektiren hareketleri yapar." kazanımlarıdır (MEB, 2013b, 80).

Etkinlikteki öykünün sözleri aracılığıyla aynı zamanda çocukların “aynı sesle başlayan sözcükler üretmeleri, aynı sesle biten sözcükler üretmeleri ve söylenen sözcükle uyaklı başka sözcük söylemeleri" sağlanabileceği gibi etkinlikteki öyküde bulunan sözcüklerin başlangıç seslerinin " $k, h, l, a, e, o, b, d, v, t, u ̈, y$ ", söylenmesi sözcüklerin sonunda yer alan seslerin " $a, s, p, n, i, z, I, e, k, u$ " söylenmesi ve öyküdeki uyakların "mış,miş,müş" söylenmesi sağlanarak okul öncesi dönemdeki çocukların ses bilgisi farkındalığının tüm göstergeleri açısından gelişimleri desteklenebilir.

\section{Tartışma}

Araştırma sonucunda özetle, Okul Öncesi Eğitim Programı Etkinlik Kitabı'nda (MEB, 2013b), "Ses bilgisi farkındalı̆̆ı gösterir." kazanımını doğrudan destekleyen herhangi bir etkinliğin olmadığı fakat farklı kazanımları desteklemek amacıyla hazırlanmış etkinlikler arasında "Ses bilgisi farkındalığı gösterir." kazanımını destekleyebilecek etkinlik örneklerinin bulunduğu belirlenmiştir. Nitekim Erdoğan, Altınkaynak ve Erdoğan (2013) da yaptıkları çalışmada, Milli Eğitim Bakanlığının (2006) Okul Öncesi Eğitim Programı'nda, kelimelerin başlangıç ve bitiş seslerini fark etme, kafiyeli kelimeler türetme gibi sesbilgisel farkındalığa yönelik kazanımlara yer verilmesine rağmen okul öncesi öğretmenlerinin büyük bir bölümünün bu kazanımlarla ilgili etkinliklere yer vermedikleri sonucuna ulaşmıştır. Ergül ve ark. (2014) ise yaptıkları çalışmada, okul öncesi öğretmenlerin erken okuryazarlık etkinliklerine ve özellikle de sesbilgisel farkındalığın geliştirilmesine yönelik etkinliklere sınırlı düzeyde yer verdiklerini ortaya koymuştur. Tuğluk, Kök, Koçyiğit, Kaya ve Gençdoğan (2008) yaptıkları çalışmada, okul öncesi öğretmenlerin okuma- yazmaya hazırlık çalışmalarında çocuklarla sözlü olarak yapılan ses çalışmalarına yeterince yer vermediklerini tespit etmiştir. Bu sonuçlardan hareketle, programda sesbilgisel farkındalığın gelişimine yönelik kazanım olmasına rağmen örnek etkinlik sunulmadığı için okul öncesi eğitimi alan çocukların sesbilgisel farkındalığı açısından desteklenemedikleri söylenebilir.

Programda ilkokula hazırlıkta temel olan becerilerin gelişimini desteklemeye yönelik örnekler arasında görsel algı çalışmalarından (el-göz koordinasyonu, şekil-zemin ayrımı, şekil sabitliği, mekânda konum, mekânsal ilişkiler, hız) sonra ikinci sırada işitsel algı çalışmaları (fonolojik duyarlılık/ farkındalık, dinleme, konuşma, sesleri hissetme, ayırt etme, aynı sesle başlayan ve biten kelimeler üretme) yer almaktadır. Programdaki bu açıklamalar göz önünde bulundurulduğunda "Ses bilgisi farkındalığı gösterir." kazanımını desteklediği düşünülen yedi etkinlikle dize veya öykü cümlelerinin sonlarında yer alan sözcüklerle çocukların dikkatlerinin ortak olan/ tekrarlanan son sese yoğunlaşmaları, sesleri hissetmeleri sağlanabileceği gibi "aynı sesle biten kelimelerin bulunması" istenerek çocukların bu sesleri diğer seslerden ayırt etmeleri de sağlanabilir. Ayrıca, "Olumlu Olumsuz" isimli etkinlikte "bir 
dairenin içine 'ayna', 'ağaç', 'at', 'ayakkabı', 'ayı', 'arı', diğer dairenin içine ise 'elma', 'etek', 'el', 'eldiven', 'ev', 'elbise' fotoğrafları koyulur." yönergesiyle birlikte verilen sözcüklerden "ağaç, ayakkabı, ayı, arı, etek" sözcükleri "a" ve "e" harflerinin sözcüğün başında ve tek başına hece olarak yer aldıkları örnekler olduğu için ön plana alınabilir. Böylece çocukların hem bu iki ünlü harfin sesini hissetmeleri hem de ayırt etmeleri kolaylaştırımış olurken "Ses bilgisi farkındalığı gösterir." kazanımının açıklamalarındaki "Bu etkinliklerde sesli harflerle çalışmak öncelikli olmalıdır." (MEB, 2013b, 26), açıklaması dikkate alınmış olacaktır. "Müze Bizi Bekler" isimli etkinlikte de tüm dizelerin son sözcüğü " $m$ " harfiyle bittiği için, çocukların bu harfin sesiyle başlayan sözcükler oluşturmaları, bu sesi hissetmeleri ve hissettikleri sesi diğer seslerden ayırt etmeleri yönünde yapılacak işitsel algı çalışmalarıyla çocukların fonolojik duyarlılık/ farkındalıkları desteklenebilecektir. Ayrıca bu durumun (dize sonlarında hep aynı ünsüzün yer alması), Illköğretim Türkçe Dersi Öğretim Programı ve Kılavuzu'ndaki (MEB, 2009, 243) sesi hissetme ve tanıma aşamasında işe koşulan "Sessiz harflerin sırasıyla kelimenin sonunda, ortasında ve başında tanıtılması" konusuna hazırlık niteliğinde olacağı düşünülebilir.

Mevcut araştırma sonuçları doğrultusunda, Okul Öncesi Eğitim Programı Etkinlik Kitabı'nın ses bilgisi farkındalığı gelişimi açısından zenginleştirilmesi adına şunlar önerilebilir:

Etkinliklerde belirtilen düzenlemelerin yanı sıra öğretmenlere etkinlik kitabı sonunda liste halinde sesbilgisel farkındalı̆ı̆n gelişimini destekleyecek çocuk kitaplarının isimleri sunulabilir. Örneğin, Gökkuşağı Şarkıları (Guarnier ve Arciprete, 2007) adlı eserde "Bu sabah güneş sarı, ve sarı mısır unu lapası, Benim topum da sarı, Yine sarı, defterin sayfası."; Uykum Gelmedi! Ali (Kozikoğlu, 2013) adlı eserde "Oysa bilse ki herkes uyur geceleri. Anneler, babalar, kuşlar, tırtıllar... Çiçekler, böcekler, saatler ve bulutlar... Herkes gözlerini kapar ve rüyaya dalar."; Kırmızı Kurbağa ve Yeşil Filamingo (Junakovic, 2005) adlı eserde "Rengi benzer yeşil yaprağa, 'Vırak vırak!' der, dalar suya. Onun adı... kurbağa." Üç Kedi Bir Dilek (Şahinkanat, 2014) adlı eserde “Neyse ki son anda kurtarıyorlar onu. Ah, ah, nereye varacak bu Piticiğin sonu?"; Çocukça (Berfe, 2006) adlı eserde "Saklambacı bulutlar oynuyor, koşmacayı yapraklar. Elim sendeyi arkadaşım oynuyor, uzun eşeği dağlar."; Maymun Kral (Şahinkanat, 2009) adlı eserde "Karar verdi biraz gölde yüzmeye. Azıcık ferahlayıp serinlemeye. Bu da yetmedi. Belki ilginç bir şey bulurum diye. Başladı ormanda gezinmeye. O da ne?"; Rüzgarın Üzerindeki Şehir (Ak, 2016) adlı eserde "Bir zamanlar ülkelerin birinde, minik bir kasabada, çalışkan ve mutlu insanlar yaşarmış. Günlerden bir gün, kasabalılar işlerinden dönerlerken, nereden geldiği belli olmayan bir rüzgar esmeye başlamış."; Bizim Tombiş Taştan Hiç Anlamıyor (Ak, 2013) adlı eserde "Birden gözüne bir şey takıldı. Bu, sahilde kendi başına duran küçük bir çakıl taşıydı." şeklindeki öykü ve dörtlüklerle öğretmenler çocukların ses bilgisi farkındalığı gelişimlerini desteklemiş olabileceklerdir. 
Okulöncesi eğitimin ardından çocuklar, ilkokul 1. sınıfa başladıklarında sese dayalı bir yöntemle okuma-yazmayı öğrenmektedir. Bu nedenle ses bilgisi farkındalığının geliştirilmesine yönelik okul öncesi dönemde yapılacak etkinliklerin okumayı öğrenme sürecine de katkı getirecektir. Okuma-yazma öğretiminde harfler, alfabedeki sıralamadan farklı bir sıra ile öğretilmektedir. Bu sıralamada harfler altı grupta ele alınmaktadır. İlk grupta "e,l,a,n" harfleri yer almaktadır. Illk grupta yer alan harflerde sesin hissettirilmesi aşamasında kullanılabilecek aşağıdaki öykü ve dörtlük örneklerine benzer örneklerden yararlanılabilir:

\section{EBELEMECE}

Elini koydu duvara,

Ebe başladı saymaya,

Emel koştu saklanmaya,

Ebemiz gitti bulmaya.

\section{TRAFIK KURALLARI}

Kaldırımda yürüyor yayalar,

Yollarda çeşit çeşit arabalar,

Levhalar ışıklar var yollarda,

Dikkat et trafik kurallarına.

GRUP ŞURUP

A vitaminin onlarda, C vitamini onlarda,

Domates, lahana.

B vitamini onlarda, E vitamini onlarda,

Fındık, fistık, nohutta.

\section{HASAN ILE ALI}

Yağmur şıp şıp damlıyor buluttan. İnsanlar kaçıyor bir yandan. Oysa çok mutluydu Ali ile Hasan. Yağmuru hissettikleri an. Derken bir kedi gördüler mırıldayan. Mır mır diyerek onlara bakan. Karnını doyurdular bu yavru kedinin. Sonra da evlerine gitti Ali ile Hasan.

\section{Kaynaklar}

Acarlar, F., Ege, P. ve Turan, F. (2002). Türk Çocuklarında Üst Dil Becerilerinin Gelişimi ve Okuma ile ilişkisi. Türk Psikoloji Dergisi, 17 (50), 63- 73.

Ak, B. (2013). Bizim Tombiş Taştan Hiç Anlamıyor. İstanbul: Günışı̆̆ı Kitaplığı.

Ak, B. (2016). Rüzgarın Üzerindeki Şehir. İstanbul: Can Çocuk Yayınları.

Akoğlu, G. ve Turan, F. (2012). Eğitsel Müdahale Yaklaşımı Olarak Sesbilgisel Farkındalık: Zihinsel Engelli Çocuklarda Okuma Becerilerine Etkileri. Hacettepe Üniversitesi Eğitim Fakültesi Dergisi, 42, 11- 22. 
Aktan, E. ve Oktay, A. (1997). Çocuğun Dil Gelişiminde Fonolojik Duyarlılığın (Sesbilgisel Duyarlılığın) Karşılaştııılmalı Olarak İncelenmesi. M. Ü. Atatürk Eğitim Fakültesi Eğitim Bilimleri Dergisi, 9, 1- 28.

Anthony, J. L. \& Francis, D. J. (2005). Development Of Phonological Awareness. Current Directions in Psychological Science, 14 (5), 255- 259.

Bay, N. D. (2008). Anasınıfı Öğretmenlerinin Okuma Yazmaya Hazırlık Çalışmalarına iliş̧kin Yeterlilik Algılarının Belirlenmesi. Yayınlanmamış Yüksek Lisans Tezi. Gazi Üniversitesi Eğitim Bilimleri Enstitüsü, Ankara.

Bayraktar, V. (2013). Okuma- Yazmaya Hazırlık Eğitim Programının Anasınıfına Devam Eden 6 Yaş Grubu Çocukların Yazı Farkındalığı Becerilerine ve IIlkokul Birinci Sınıftaki Ses Farkındalığı ve Okuma- Yazma Becerilerine Etkisinin Incelenmesi. Ankara: Gazi Üniversitesi Eğitim Bilimleri Enstitüsü, Yayınlanmamış Doktora Tezi.

Berfe, S. (2006). Çocukça. Ankara: Tudem Yayınları.

Chard, D. J. \& Dickson S. V. (1999). Phonological Awareness: Instructional and Assesment Guideliness. Intervention in School and Clinic, 34 (5), 261- 270.

Cramer, D. E. (2006). In The Beginning: Phonological Awareness. In J.Shay Schumm (Ed.), Reading Assessment and Instruction For All Learners (pp. 89- 117). New York, NY: Guilford Press.

Ekici, S. (2014). Ankara'daki Anaokullarının Okuma Alışkanlığına Hazırlık Yeterlilikleri Açısından Değerlendirilmesi. Ankara: Hacettepe Üniversitesi Sosyal Bilimler Enstitüsü, Yayınlanmamış Yüksek Lisans Tezi.

Erduran, E. (1999). Okul Öncesi Eğitimde Okuma- Yazmaya Hazırlık Programları ve Bilişsel Yetenek Özelliklerinin Okuma Sürecine Etkileri. İstanbul: Marmara Üniversitesi Eğitim Bilimleri Enstitüsü, Yayınlanmamış Yüksek Lisans Tezi.

Erdoğan, Ö. (2009). Ilköğretim Birinci Sınıf Öğrencilerinin Fonolojik Farkındalık Becerileri ile Okuma ve Yazma Becerileri Arasındaki ilişski. Ankara: Hacettepe Üniversitesi Sosyal Bilimler Enstitüsü, Yayınlanmamış Yüksek Lisans Tezi.

Erdoğan, Ö. (2011). İlk Okuma-Yazma Süreci İçin Önemli Bir Beceri: Fonolojik Farkındalık. Uludağ Üniversitesi Eğitim Fakültesi Dergisi, 24 (1), 161- 180.

Erdoğan, Ö. (2012). İlköğretim Birinci Sınıf Öğrencilerinin Fonolojik Farkındalık Becerileri İle Okuma Becerileri Arasındaki İlişki. Eğitim ve Bilim, 37 (166), 41- 51.

Erdoğan, T., Altınkaynak, Ş. Ö. ve Erdoğan, Ö. (2013). Okul Öncesi Öğretmenlerinin Okuma- Yazmaya Hazırlığa Yönelik Yaptıkları Çalışmaların İncelenmesi. Ilköğretim Online, 12 (4), 1188- 1199, [Online]: http://ilkogretim-online.org.tr/vol12say4/v12s4m20.pdf adresinden 10 Ağustos 2015 tarihinde indirilmiştir.

Ergül, C., Karaman, G., Akoğlu, G., Tufan, M., Sarıca, A. D., Kudret, Z. B. (2014). Okul Öncesi Öğretmenlerinin 'Erken Okuryazarlık' Kavramına İlişkin Bilgi Düzeyleri ve Sınıf Uygulamaları. IIlköğretim Online, 13 (4), 1449- 1472, [Online]: http://ilkogretim-online.org.tr/vol13say4/v13s4m19.pdf adresinden 10 Ağustos 2015 tarihinde indirilmiştir.

Guarnier, R. ve Arciprete, C. (2007). Gökkuşağı Şarkıları. (Çev: Kübra Bahar) İstanbul: Boyut Yayın Grubu. 
Güldenoğlu, B., Kargın, T., ve Ergül, C. (2016). Sesbilgisel Farkındalık Becerilerinin Okuma ve Okuduğunu Anlama Üzerindeki Etkisi: Boylamsal Bir Çalışma. Ilköğretim Online, 15 (1), 251 - 272.

Gürkan, T. ve Koran, N. (2014). 36- 72 Aylık Çocuklar İçin Okul Öncesi Eğitim Programı'nın Çocuğun Katılım Hakkına Yer Verme Durumu Açısından İncelenmesi. Journal of Teacher Education and Educators, 3 (2), 203- 226.

Hempenstall, K. (2003). Phonemic Awareness: What Does It Mean? [Online]: http://www.ednews.org/articles/523/1/Phonemic-awareness-What-doesitmean/Page1.html adresinden 11 Ağustos 2015 tarihinde indirilmiştir.

Junakovic, S. (2005). Kırmızı Kurbağa ve Yeşil Filamingo. İstanbul: Tudem Yayınları.

Karakelle, S. (1998). Ilkokuma Becerisinin Kazanılmasını Etkileyen Bilişsel Faktörler. Ankara: Hacettepe Üniversitesi Sosyal Bilimler Enstitüsü, Yayınlanmamış Doktora Tezi.

Karakelle, S. (2004). Fonolojik Farkındalık ve Harf Bilgisinin İlkokuma Becerisi Üzerindeki Etkisi, İstanbul Üniversitesi Psikoloji Çalışmaları Dergisi, 24, 45- 56.

Karaman, G. ve Üstün, E. (2011). Anasınıfına Devam Eden Çocukların Fonolojik Duyarlılıklarının Bazı Değişkenlere Göre İncelenmesi. Hacettepe Üniversitesi Eğitim Fakültesi Dergisi, 40, 267- 278.

Kerem, E. A. (2001). Okul Öncesi Dönem Çocuklarında Okuma Gelişimi ve Okumaya Hazırlık Programının Etkisinin Değerlendirilmesi. İstanbul: Marmara Üniversitesi Eğitim Bilimleri Enstitüsü, Yayınlanmamış Doktora Tezi.

Kesikçi, H. ve Amado, S. (2005). Okuma Güçlüğü Olan Çocukların Fonolojik Bellek, Kısa Süreli Bellek Ve WISC-R Testi Puanlarına Ait Bir İnceleme. Türk Psikoloji Dergisi, 20 (55), 99- 110.

Kılıç, Z. (2008). Ilköğretim Birinci Sınıf Öğretmenlerinin Görüşlerine Göre Okul Öncesi Eğitimi Alan ve Almayan Öğrencilerin Gelişim Becerilerinin Karşılaştırılması. İstanbul: Beykent Üniversitesi, Yayınlanmamış Yüksek Lisans Tezi.

Kozikoğlu, T. (2013). Hiç Uykum Gelmedi! Ali. İstanbul: Illetişim Yayınevi.

Lane, H. B., Pullen, P. C., Eisele, M. R., \& Jordan, L. (2002). Preventing Reading Failure: Phonological Awareness Assessment and Instruction. Preventing School Failure, 46, 101-110.

Mc Gee, L. \& Ukrainetz, T. (2009). Using Scaffolding to Teach Phonemic Awareness In Preschool and Kindergarten. The Reading Teacher, 62, 599- 603.

MEB. (2009). Ilköğretim Türkçe Dersi Öğretim Programı ve Kılavuzu 1.-5. Sınıflar. Ankara: Devlet Kitapları Müdürlüğü Basımevi.

MEB. (2013a). Okul Öncesi Eğitim Programı. Milli Eğitim Bakanlığı Temel Eğitim Genel Müdürlüğü. Ankara: Milli Eğitim Basımevi. [Online]: http://www.onceokuloncesi.com/okuloncesi egitimprogrami.pdf adresinden 28 Ağustos 2015 tarihinde indirilmiştir.

MEB. (2013b). Okul Öncesi Eğitim Programı Etkinlik Kitabı. [Online]: http://anaokulu.cu.edu.tr/ /file/OOEP 2013 Etkinlik_Kitabi.pdf adresinden 25 Ağustos 2015 tarihinde indirilmiştir.

Özcan, A. O. ve Özcan, A. F. (2014). Türk Çocuklarının Ses Gelişim Özellikleri ve İlk Okuma Yazma Öğrenme. İstanbul Gelişim Üniversitesi Sosyal Bilimler Dergisi, 1 (2), 67- 86. 
Pehlivan, D. (2006). Okul Öncesi Eğitimi Alan ve Almayan Öğrencilerin Ilk Okuma Yazmaya Geçiş Sürecinin, Öğretmen ve Öğrenci Görüşleri Doğrultusunda Değerlendirilmesi. Adana: Çukurova Üniversitesi Sosyal Bilimler Enstitüsü, Yayınlanmamış Yüksek Lisans Tezi.

Roskos, K. A., Christie J. F. ve Richgelds, D. J. (2003). The Essentials Of Early Literacylnstruction,[Online]:https://www.naeyc.org/files/yc/file/200303/Essentials.pdf adresinden 11 Ağustos 2015 tarihinde indirilmiştir.

Sarı, B. (2012). Erken Çocukluk Dönemi Fonolojik Duyarlılık Ölçeği (EÇDFDÖ)’nin Geçerlik, Güvenirlik ve Norm Çalışması. Çanakkale Onsekiz Mart Üniversitesi Eğitim Bilimleri Enstitüsü, Yayınlanmamış Yüksek Lisans Tezi.

Sayar, F. ve Turan, F. (2012). Okuma Gelişiminde Üst Dil Farkındalığı, Sesbilgisel Süreçler ve Bellek Süreçlerinin Etkisi: Kısa Süreli Bellek ve Çalışma Belleği. Ankara Üniversitesi Eğitim Bilimleri Fakültesi Özel Eğitim Dergisi, 13 (2), 49- 64.

Stanovich, K. E. (1986). Matthew Effects In Reading: Some Consequences of Individual Differences In The Acquisition Of Literacy. Reading Research Quarterly, 22, 360- 407.

Süel, E. E. (2011). IIlköğretim 1. Sınıf Üstün ve Normal Zeka Düzeyindeki Öğrencilerin Fonolojik Farkındalık Düzeylerinin Okuma Başarıları Üzerine Etkisinin Karşılaştırılması. İstanbul Üniversitesi Sosyal Bilimler Enstitüsü, Yayınlanmamış Yüksek Lisans Tezi.

Şahinkanat, S. (2009). Maymun Kral. İstanbul: Yapı Kredi Yayınları.

Şahinkanat, S. (2014). Üç Kedi Bir Dilek (6. Baskı). İstanbul: Yapı Kredi Yayınları.

Tuğluk, İ. H., Kök, M., Koçyiğit, S. Kaya H. İ ve Gençdoğan, B. (2008). Okul Öncesi Öğretmenlerinin Okuma- Yazma Etkinliklerini Uygulamaya İlişkin Görüşlerinin Değerlendirilmesi. Atatürk Üniversitesi Kazım Karabekir Eğitim Fakültesi Dergisi, 17, 72- 81.

Turan, F. ve Akoğlu, G. (2011). Okul Öncesi Dönemde Sesbilgisel Farkındalık Eğitimi. Eğitim ve Bilim, 36 (161), 64 75.

Turan, F. ve Gül, G. (2008). Okumanın Erken Dönemindeki Habercisi: Sesbilgisel Farkındalık Becerisinin Kazanımı. Kuram ve Uygulamada Eğitim Bilimleri, 8 (1), 265- 284.

Uyanık, Ö. ve Kandır, A. (2010). Okul Öncesi Dönemde Erken Akademik Beceriler. Kuramsal Eğitimbilim, 3 (2), 118- 134.

Yıldııım, A. ve Şimşek, H. (2008). Sosyal Bilimlerde Nitel Araştırma Yöntemleri. Ankara: Seçkin Yayınevi.

Yücel, D. (2009). Sesbilgisel Farkındalık (Fonolojik Farkındalık) Eğitiminin Okuma Sorunu Olan Çocuklar Üzerindeki Etkisinin Incelenmesi. Ankara: Hacettepe Üniversitesi Sağlık Bilimleri Enstitüsü, Yayınlanmamış Yüksek Lisans Tezi.

Not: “Ebelemece” başlıklı dörtlüğ̈̈ yazan sınıf öğretmeni adayı Nursel ŞAHiN ve "Hasan ile Ali” isimli öyküyü yazan sınıf öğretmeni adayı Özlem DEMiREL'e katkıları için teşekkür ediyoruz. 